\title{
Modelling and forecasting the workplace environmental physical factors values
}

\author{
O. Kruzhilko a,*, R. Cherneha ${ }^{b}$, V. Maystrenko a, \\ O. Polukarov c, V. Kalinchyk c \\ a Public Agency "National Scientific and Research Institute of Industrial Safety \\ and Occupational Safety and Health", 04060, Vavilovykh str.,13, Kyiv, Ukraine \\ b State Labour Service of Ukraine, 01601, Desyatynna str., 14, Kyiv, Ukraine \\ c National Technical University of Ukraine "Igor Sikorsky Kiev Polytechnic Institute", \\ 03056, Prosp. Peremohy, 37, Kyiv, Ukraine \\ * Corresponding e-mail address: olkruzhilko@ukr.net
}

\section{ABSTRAGT}

Purpose: To develop a mathematical model for predicting the workplace environmental physical factors values.

Design/methodology/approach: Experimental measurements of the harmful and dangerous physical factors values of workplace environmental were carried out using special certified equipments. For each physical factor, 200 measurements were carried out. The workplace choice is justified by the employees' survey and specialists' expert evaluation results. Prediction methods that can be used to predict the workplace environmental physical factors values have been analyzed analytically. Working conditions assessment was carried out in accordance with the classification of working conditions for workplace harmfulness and danger, which function in Ukraine.

Findings: For a preliminary assessment of the impact of environmental physical factors on workers, it is proposed to use the strict ranking method. It has been established that the proposed mathematical models for predicting the workplace environmental physical factors values (noise, dust, vibration, relative humidity) have an accuracy of more than $90 \%$ and can be used for planning measures to working conditions improve.

Research limitations/implications: The results of a study of modelling and forecasting the workplace environmental physical factors values at the enterprise for the manufacture of glass and glass products at workplaces of transportation, preparation and mixing of materials are shown. Mathematical models for four physical factors are presented: noise, dustiness of air, vibration, relative humidity.

Practical implications: Mathematical models make it possible to predict the environmental physical factors values (noise, vibration, dust, humidity) taking into account the specifics of the production process, assess the hazard class and harmfulness of working conditions at workplaces and justify the measures at labour protection.

Originality/value: For the first time proposed by the mathematical models for predict the environmental physical factors values (noise, vibration, dust, humidity) taking into account the specifics of the production process.

Keywords: Safety and health management, Environmental physical factors, Prediction methods, Strict ranking method 


\section{Reference to this paper should be given in the following way:}

O. Kruzhilko, R. Cherneha, V. Maystrenko, O. Polukarov, V. Kalinchyk, Modelling and forecasting the workplace environmental physical factors values, Archives of Materials Science and Engineering 100/1-2 (2019) 21-33.

\section{MATERIALS MANUFAGTURING AND PROCESSING}

\section{Introduction}

The manufacturing processes, as a rule, is accompanied by the presence of harmful and dangerous physical factors (noise [1,2], thermal radiation [3,4], workplace air dustiness [5-8], vibration [9,10], injury danger [11-13], increased or decreased relative humidity $[14,15]$ etc.) that adversely affect human health.

Depending on the quantitative characteristics (level, concentration, etc.) and the duration of exposure, the physical factor can become harmful, and the harmful production factor can become dangerous.

As practice shows, the introduction of the latest methods of labour protection management is slow. Therefore, there is a need to develop new and improve existing tools to improve the safety level in the workplace. Many scientists intensively develop methods for assessing production risks as an influence result to workers of many workplace environmental physical factors $[16,17]$.

An analysis of scientific papers indicates the presence of algorithms, techniques and methods designed to identify causal relationships between various factors and the level of production risk [18,19]. At the same time, it should be noted that when assessing risk, the characteristics of enterprises of various industries are not sufficiently taken into account, which does not always allow an adequate assessment of the level of production risk. Moreover, the assessment results are not fully used for development of preventive measures to reduce the occupational injuries and occupational morbidity level.

Thus, when assessing working conditions, it is important to take into account the production specifics by adequately assessing the influence of workplace environmental physical factors on the health of workers.

In study [20], the authors proposed Improvement of the workplace environmental physical factors values monitoring by determining the optimal interval for their control. Based on the identified of change patterns in the workplace environmental physical factors values that were identified in study [20], in this study the purpose was to develop a mathematical model to predict the levels of these physical factors.

\section{Materials and methods}

To achieve the purpose were applied: analysis and synthesis of known scientific results on the topic of research, statistical analysis, mathematical modelling.

Experimental measurements of the harmful and dangerous physical factors values of workplace environmental were carried out using special certified equipments at workplaces in the workshop for the transportation, preparation and mixing of materials for glass and glass products. The noise, working environment air dustiness, vibration and relative humidity were measured in accordance with the methodology presented in the previous study [20].

For each physical factor, 200 measurements were carried out. The workplace choice is justified by the employees' survey and specialists' expert evaluation results. Prediction methods that can be used to predict the workplace environmental physical factors values have been analyzed analytically. According to these results, the workshop for transportation, preparation and mixing of materials is defined as the workshop with the most harmful working conditions at the enterprise.

Prediction methods that can be used to predict the workplace environmental physical factors values have been analyzed analytically.

Working conditions assessment was carried out in accordance with the classification of working conditions for workplace harmfulness and danger, which function in Ukraine [21]. Table 1 presents the working conditions classes by some workplace environmental physical factors.

\section{Results and discussion}

\subsection{Prediction methods analysis}

Analytical analysis of prediction methods [22-24] based on a comparison of five indicators of each method is shown in Table 2. 
Table 1.

Working conditions classes by some environmental physical factors in workplace [21]

\begin{tabular}{|c|c|c|c|c|c|c|c|c|}
\hline \multirow{2}{*}{ No. } & \multirow{2}{*}{\multicolumn{2}{|c|}{$\begin{array}{l}\text { Name of workplace } \\
\text { environmental physical factors, } \\
\text { (units) }\end{array}$}} & \multirow{2}{*}{$\begin{array}{l}\text { Maximum permissible } \\
\text { concentration (MPC), } \\
\text { acceptable level }\end{array}$} & \multicolumn{5}{|c|}{ Working conditions class } \\
\hline & & & & $3(1)$ & $3(2)$ & $3(3)$ & $3(4)$ & 4 \\
\hline \multirow{2}{*}{1} & \multirow{2}{*}{\multicolumn{2}{|c|}{ Noise, dBA }} & \multirow{2}{*}{$<80$} & \multicolumn{5}{|c|}{ The sound levels, up to (inclusive) } \\
\hline & & & & 85 & 95 & 105 & 115 & $>115$ \\
\hline \multirow[t]{2}{*}{2} & \multirow{2}{*}{\multicolumn{2}{|c|}{ Local vibration, $\mathrm{dB}$}} & \multirow[t]{2}{*}{112} & \multicolumn{5}{|c|}{$\begin{array}{l}\text { The exceeding the maximum permissible level } \\
\text { (MPL), to the specified value (inclusive) }\end{array}$} \\
\hline & & & & $3 / 1.4$ & $6 / 2$ & $9 / 2.8$ & $12 / 4$ & $>12 / 4$ \\
\hline \multirow[b]{2}{*}{3} & \multirow{2}{*}{\multicolumn{2}{|c|}{ Dust, $\mathrm{mg} / \mathrm{m}^{3}$}} & \multirow[b]{2}{*}{ MPC for each substance } & \multicolumn{5}{|c|}{ The multiplicity of excess MPC, times } \\
\hline & & & & $1.1-3.0$ & $\begin{array}{l}3.1- \\
10.0\end{array}$ & $\begin{array}{l}10.1- \\
15.0\end{array}$ & $>15.0$ & - \\
\hline \multirow{3}{*}{4} & \multirow{3}{*}{$\begin{array}{l}\text { Relative } \\
\text { humidity, \%: }\end{array}$} & & \multirow{2}{*}{$\begin{array}{l}65 \\
\text { at } 26^{\circ} \mathrm{C}\end{array}$} & \multicolumn{5}{|c|}{ The exceeding the MPL, $\%$} \\
\hline & & Warm season & & $\begin{array}{l}\text { less } \\
\text { than } 25\end{array}$ & $\begin{array}{l}\text { more } \\
\text { than } 25\end{array}$ & - & - & - \\
\hline & & Cold season & 75 & $\begin{array}{l}\text { less } \\
\text { than } 15\end{array}$ & $\begin{array}{l}\text { more } \\
\text { than } 25\end{array}$ & & & \\
\hline
\end{tabular}

Table 2.

Comparison results of prediction methods

\begin{tabular}{|c|c|c|c|c|c|}
\hline Method name & $\begin{array}{l}\text { Takes into account } \\
\text { seasonality / trend }\end{array}$ & $\begin{array}{l}\text { Transparency of } \\
\text { modelling }\end{array}$ & $\begin{array}{l}\text { Ability to modelling } \\
\text { nonlinear processes }\end{array}$ & Adaptability & Flexibility \\
\hline Linear regression model & Yes / No & Yes & No & No & Yes \\
\hline Multiple regression model & Yes / No & Yes & No & No & Yes \\
\hline $\begin{array}{l}\text { Nonlinear regression } \\
\text { model }\end{array}$ & Yes / No & Yes & No & No & Yes \\
\hline $\begin{array}{l}\text { Model of group } \\
\text { accounting of arguments }\end{array}$ & Yes / Yes & No & Yes & Yes & Yes \\
\hline $\begin{array}{l}\text { Autoregressive model of } \\
\text { moving average }\end{array}$ & Yes / No & Yes & No & No & Yes \\
\hline $\begin{array}{l}\text { Exponential smoothing } \\
\text { method }\end{array}$ & Yes / No & Yes & Yes & Yes & No \\
\hline Holt model & Yes / No & Yes & Yes & Yes & No \\
\hline Holt-Winters model & Yes / Yes & Yes & Yes & Yes & No \\
\hline
\end{tabular}

According to the results of the analysis, it was found that the advantages of certain prediction methods [25] are determined mainly by the temporal characteristics and accuracy of forecasts. In this case, the exponential smoothing method and the autoregressive model for onedimensional processes are reduced to each other. The accuracy of these methods does not differ significantly. However, in terms of ease of implementation and calculation time, the exponential smoothing method has a significant advantage.

The essence of the exponential smoothing method is that the forecast values are constantly reviewed when new data arrives. As observations grow older, the exponential smoothing model gives them exponentially declining weights, so past observations have less impact on predicted values compared to the latest available data [25]. 
To predict non-stationary processes, the use of the wellknown method of polynomial regression has been proposed.

The exponential smoothing model of stationary processes is determined by the equation:

$$
\begin{aligned}
& y(t)=S(t)+\varepsilon_{t}, \\
& S(t)=\alpha \cdot x(t-1)+(1-\alpha) \cdot S(t-1),
\end{aligned}
$$

where $\alpha$ - the smoothing factor, $0<\alpha<1$; $\mathrm{S}(\mathrm{t})$ - smoothed out value $(S(t)=x(0)-$ initial conditions $)$.

Based on equation (1), each new smoothed value $\mathrm{S}(\mathrm{t})$ is a weighted average between the previous value of the time series $\mathrm{x}(\mathrm{t})$ and the previous smoothed value $\mathrm{S}(\mathrm{t}-1)[25]$.

When predicting conditionally stationary processes, it is proposed to express the predictive model in the form (2)

$y(t)=y_{1}(t)+y_{2}(t)$

where $\mathrm{y}_{2}(\mathrm{t})$ - conditional stationary part; $\mathrm{y}_{1}(\mathrm{t})$ - trending part.

The trend part has the form

$\mathrm{y}_{1}(\mathrm{t})=\sum_{\mathrm{i}=0}^{\mathrm{n}} \alpha_{\mathrm{i}} \mathrm{t}^{\mathrm{i}}$

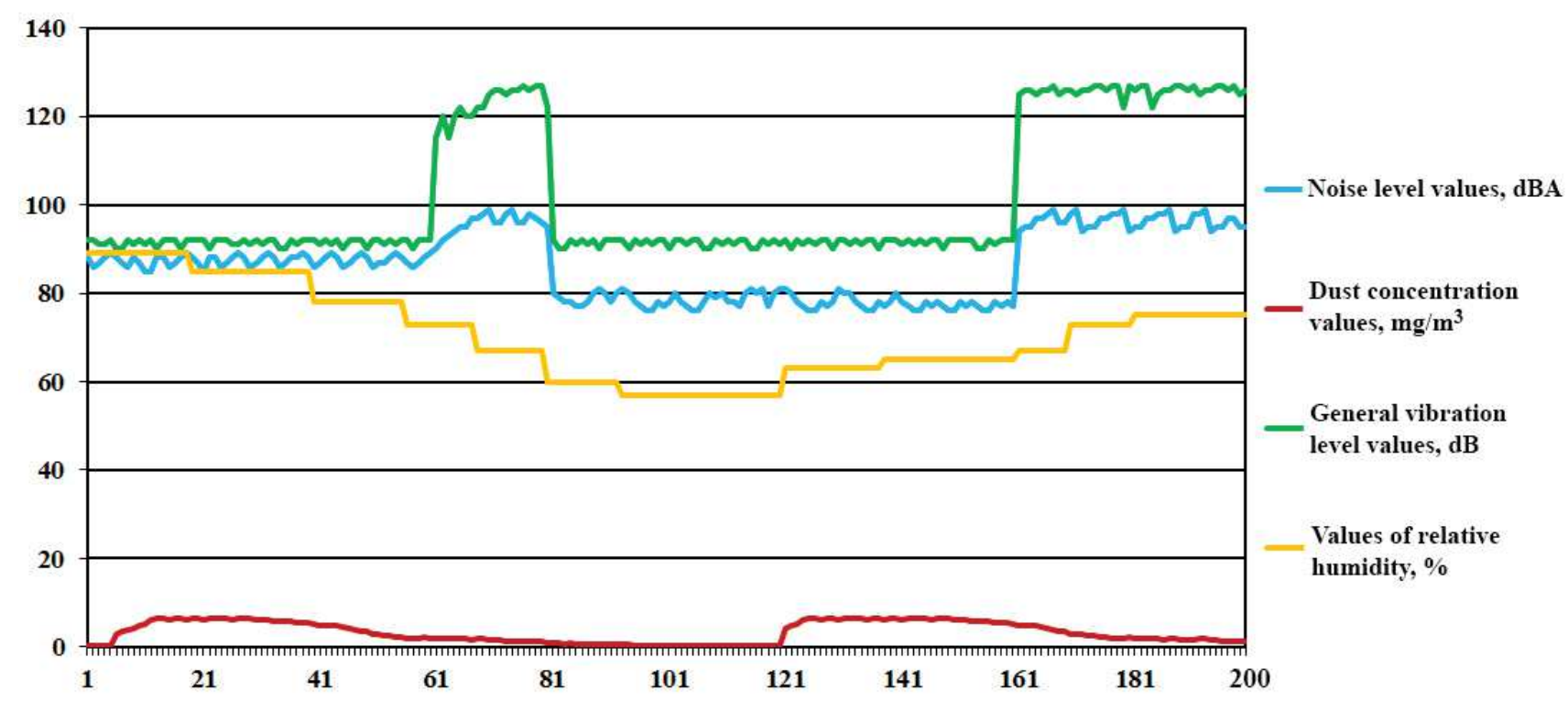

Fig. 1. Experimental data of the environmental physical factors values dynamics at workplaces of transportation, preparation and mixing of materials of the manufacture of glass and glass products
To predict the trend part of forecast models for conditionally stationary processes, it is proposed to use the polynomial regression method.

The forecast model quality (that is, the possibility of using it to solve problems in real production conditions) is determined by its accuracy and is a future process adequacy measure. To prediction accuracy assesses of the workplace environmental physical factors values, it is proposed to use the absolute $\left(\mathrm{e}_{\alpha}\right)$ and relative $\left(\mathrm{e}_{\beta}\right)$ errors are calculated according to the formulas:

$e_{\alpha}^{i}(t)=x_{i}(t)-y_{i}(t)$

$\mathrm{e}_{\beta}=\sum_{\mathrm{i}=1}^{\mathrm{n}}\left|\frac{\mathrm{x}_{\mathrm{i}}(\mathrm{t})-\mathrm{y}_{\mathrm{i}}(\mathrm{t})}{\mathrm{x}_{\mathrm{i}}(\mathrm{t})}\right| \cdot 100 \%$,

where $x(t)$ - the actual workplace environmental physical factors value at the i-th moment; $y(t)$ - the calculated workplace environmental physical factors value at the i-th moment.

That is, the relative forecasting error of the proposed model is estimated by the average deviation modulus of the actual and the calculated value of the simulated indicator (taken in percent). The forecasting accuracy of the proposed model $\left(\mathrm{z}_{\Pi}\right)$ is estimated by the formula:

$\mathrm{z}_{\Pi}=100-\mathrm{e}_{\beta}$ 
Using this approach to forecasting, a prediction model was created, which has the necessary accuracy, for such physical factors as noise, vibration, dust, and relative humidity.

The experimental values of workplace environmental physical factors as noise, vibration, dust, and relative humidity that is shown in Figure 1 was analysed.

\subsection{Workplace noise level values modelling and forecasting}

Since the variation coefficient for this factor is $7.35 \%$, that is, it is within $15 \%$, the process describing the noise level changes dynamics is conditionally stationary [20]. Testing of experimental data was carried out and shown in a previous study [20] (Tab. 3). According to the Table 3 it was found that the best results of forecasting noise indicators in the working area of transportation, preparation and mixing of materials were obtained for the smoothing coefficient. Based on equation (1), each new smoothed value $\mathrm{S}(\mathrm{t})$ is a weighted average between the previous value of the time series and the previous smoothed value [25].

The sample for building the forecast was the first six points, and the control sample was 15 calculated forecast points. The calculation results are shown in Table 4 . The relative forecast error is $6.17 \%$.

The noise level forecast model has the form:

$$
\begin{aligned}
& y(t)=0.3 \cdot x(t-9)+0.7 \cdot S(t-10) \\
& S(0)=\frac{1}{6} \sum_{i=1}^{6} x(9 \cdot(i-1)+1)
\end{aligned}
$$

The noise level dynamics at workplaces (factual and calculated data) are shown at Figure 2.

Table 3.

Experimental data processing results [20]

\begin{tabular}{llllll}
\hline No. & $\begin{array}{l}\text { Name of environmental } \\
\text { physical factors on the } \\
\text { workplace }\end{array}$ & $\begin{array}{l}\text { Number of } \\
\text { measurements }(\mathrm{n})\end{array}$ & $\begin{array}{l}\text { Correlation } \\
\text { coefficient }(\mathrm{R})\end{array}$ & $\begin{array}{l}\text { Period of } \\
\text { stationarity }(\mathrm{T}), \\
\text { min }\end{array}$ & $\begin{array}{l}\text { Interval of control } \\
(\bar{\Delta}), \min \end{array}$ \\
\hline 1 & Noise & 200 & 0.88 & 28 & 9 \\
\hline 2 & Vibration & 200 & 0.77 & 20 & 7 \\
\hline 3 & Dust & 200 & 0.76 & 9 & 3 \\
\hline 4 & Relative humidity & 200 & 0.81 & 66 & 22 \\
\hline
\end{tabular}

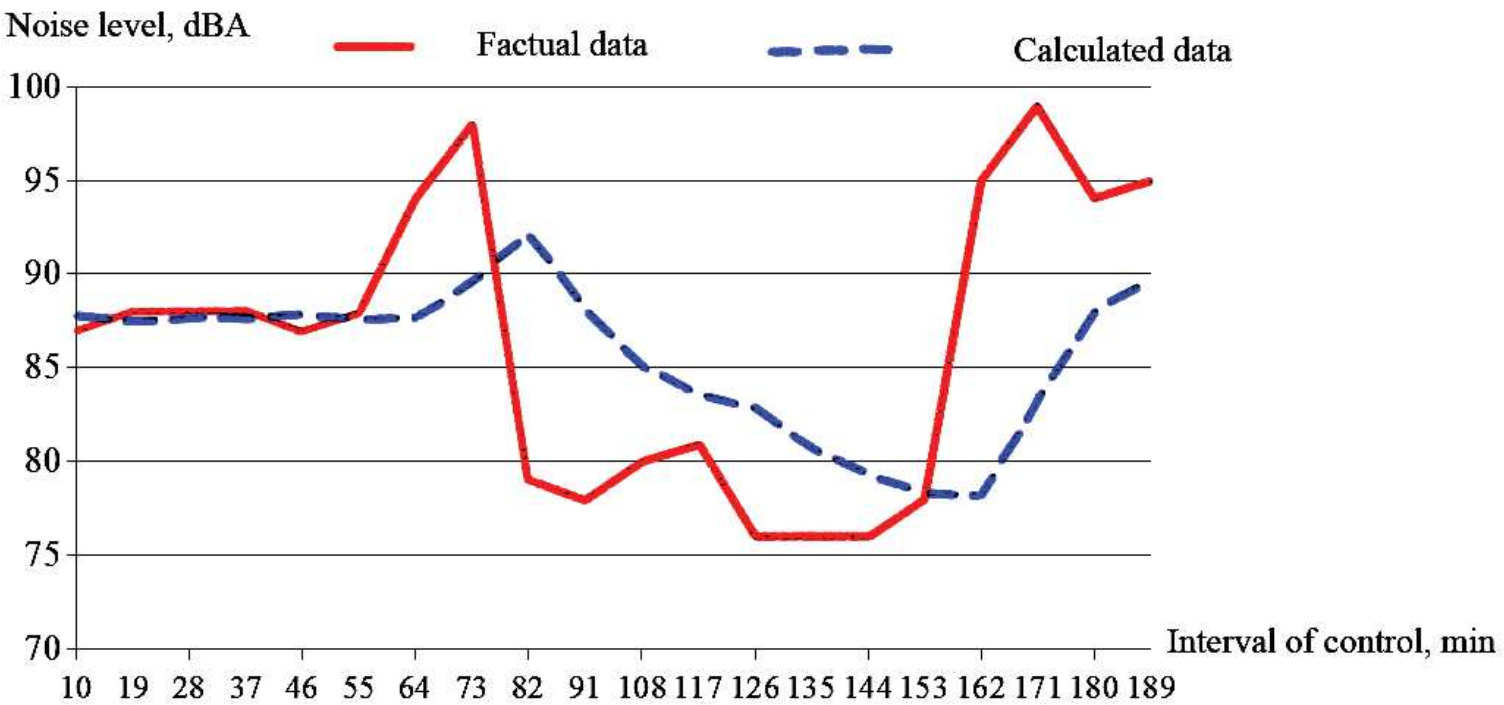

Fig. 2. The noise level dynamics at workplaces (factual and calculated data) 
Table 4.

The predicted values calculation results of the noise level

\begin{tabular}{|c|c|c|c|c|c|c|c|}
\hline \multirow{3}{*}{$\begin{array}{l}\text { Interval of } \\
\text { control, min }\end{array}$} & \multirow{3}{*}{$\begin{array}{l}\text { Factual data } \\
x(t), d B A\end{array}$} & \multicolumn{6}{|c|}{ Predicted values calculation results } \\
\hline & & \multicolumn{2}{|l|}{$\alpha=0.3$} & \multicolumn{2}{|l|}{$\alpha=0.2$} & \multicolumn{2}{|c|}{$\alpha=0.5$} \\
\hline & & $\mathrm{e}_{\alpha}$ & $\mathrm{y}(\mathrm{t}), \mathrm{dBA}$ & $\mathrm{e}_{\alpha}$ & $\mathrm{y}(\mathrm{t}), \mathrm{dBA}$ & $\mathrm{e}_{\alpha}$ & $y(t), d B A$ \\
\hline 1 & 88 & - & - & - & - & - & - \\
\hline 10 & 87 & 87.77 & -0.77 & 87.64 & -0.64 & 88.00 & -1.00 \\
\hline 19 & 88 & 87.54 & 0.46 & 87.51 & 0.49 & 87.90 & 0.10 \\
\hline 28 & 88 & 87.68 & 0.32 & 87.61 & 0.39 & 87.91 & 0.09 \\
\hline 37 & 88 & 87.77 & 0.23 & 87.69 & 0.31 & 87.92 & 0.08 \\
\hline 46 & 87 & 87.84 & -0.84 & 87.75 & -0.75 & 87.93 & -0.93 \\
\hline 55 & 88 & 87.59 & 0.41 & 87.60 & 0.40 & 87.83 & 0.17 \\
\hline 64 & 94 & 87.71 & 6.29 & 87.68 & 6.32 & 87.85 & 6.15 \\
\hline 73 & 98 & 89.60 & 8.40 & 88.94 & 9.06 & 88.47 & 9.53 \\
\hline 82 & 79 & 92.12 & -13.12 & 90.75 & -11.75 & 89.42 & -10.42 \\
\hline 91 & 78 & 88.18 & -10.18 & 88.40 & -10.40 & 88.38 & -10.38 \\
\hline 108 & 80 & 85.13 & -5.13 & 86.32 & -6.32 & 87.34 & -7.34 \\
\hline 117 & 81 & 83.59 & -2.59 & 85.06 & -4.06 & 86.61 & -5.61 \\
\hline 126 & 76 & 82.81 & -6.81 & 84.25 & -8.25 & 86.05 & -10.05 \\
\hline 135 & 76 & 80.77 & -4.77 & 82.60 & -6.60 & 85.04 & -9.04 \\
\hline 144 & 76 & 79.34 & -3.34 & 81.28 & -5.28 & 84.14 & -8.14 \\
\hline 153 & 78 & 78.34 & -0.34 & 80.22 & -2.22 & 83.32 & -5.32 \\
\hline 162 & 95 & 78.24 & 16.76 & 79.78 & 15.22 & 82.79 & 12.21 \\
\hline 171 & 99 & 83.27 & 15.73 & 82.82 & 16.18 & 84.01 & 14.99 \\
\hline 180 & 94 & 87.99 & 6.01 & 86.06 & 7.94 & 85.51 & 8.49 \\
\hline 189 & 95 & 89.79 & 5.21 & 87.65 & 7.35 & 86.36 & 8.64 \\
\hline \multicolumn{3}{|c|}{ Relative error, $\%$} & 6.17 & & 6.92 & & 7.52 \\
\hline
\end{tabular}

Thus, it was established that a significant part of the working time due to the noise factor at workplaces is spent in harmful working conditions (see Tab. 1). Working conditions correspond to subclass 3(1) (80...85 dBA) and subclass 3(2) (85...95 dBA), and in certain time periods work occurs in harmful working conditions of subclass 3(3) (95...105 dBA). The analysis results indicate that to reduce the harmful noise effects, it is necessary to carry out measures to improve working conditions.

\subsection{Workplace dust concentration values modelling and forecasting}

The dust concentration values dynamics was analyzed for experimental data that are shown in Figure 1.

As the calculations show, the variation in the mathematical expectation for this factor is $133 \%$, which is outside the range of $10 \%$, that is, the process is nonstationary and so a trend model was created. 
It was found that the best results for predicting the dust concentration values $\left(\mathrm{SiO}_{2}\right.$ at a concentration of more than $60 \%$ ) in the air of the working zone were obtained for a fourth-order model. The correlation coefficient for this model is $\mathrm{R}=0.99$ and the relative forecast error is $9.76 \%$.

The forecast model for dust concentration is:

$$
y(t)=2.2+0.367 t-0.0065 t^{2}-0.000077 t^{3}+0.0000012 t^{4}
$$

The predicted values calculation results of the dust concentration are shown in Table 5 and the graphical representation of the dynamics of the factual and calculated values of the dust concentration are shown in Figure 3.

Table 5.

The predicted values calculation results of the dust concentration

\begin{tabular}{llll||llll}
\hline Factual data & \multicolumn{3}{c}{$\begin{array}{l}\text { Predicted values calculation } \\
\text { results }\end{array}$} & \multicolumn{2}{l}{ Factual data } & \multicolumn{3}{c}{$\begin{array}{l}\text { Predicted values calculation } \\
\text { results }\end{array}$} \\
\hline $\mathrm{t}, \mathrm{min}$ & $\mathrm{x}(\mathrm{t}), \mathrm{M \Gamma} / \mathrm{M}^{3}$ & $\mathrm{y}(\mathrm{t}), \mathrm{M \Gamma} / \mathrm{M}^{3}$ & $\begin{array}{l}\text { Absolute } \\
\text { error }\end{array}$ & $\mathrm{t}, \mathrm{min}$ & $\mathrm{x}(\mathrm{t}), \mathrm{M \Gamma} / \mathrm{M}^{3}$ & $\mathrm{y}(\mathrm{t}), \mathrm{M \Gamma} / \mathrm{M}^{3}$ & $\begin{array}{l}\text { Absolute } \\
\text { error }\end{array}$ \\
\hline 1 & 3 & 2.56 & 0.44 & 31 & 6 & 6.14 & -0.14 \\
\hline 4 & 3 & 3.56 & -0.56 & 34 & 5.7 & 5.74 & -0.04 \\
\hline 7 & 4.1 & 4.43 & -0.33 & 37 & 5.4 & 5.24 & 0.16 \\
\hline 10 & 5 & 5.15 & -0.15 & 40 & 4.7 & 4.64 & 0.06 \\
\hline 13 & 6.4 & 5.73 & 0.67 & 43 & 4 & 3.98 & 0.02 \\
\hline 16 & 6.5 & 6.17 & 0.33 & 46 & 3.7 & 3.27 & 0.43 \\
\hline 19 & 6.5 & 6.45 & 0.05 & 49 & 2.2 & 2.52 & -0.32 \\
\hline 22 & 6.5 & 6.58 & -0.08 & 52 & 1.9 & 1.78 & 0.12 \\
\hline 25 & 6.3 & 6.57 & -0.27 & 55 & 0.7 & 1.06 & -0.36 \\
\hline 28 & 6.2 & 6.42 & -0.22 & 58 & 0.6 & 0.40 & 0.20 \\
\hline
\end{tabular}

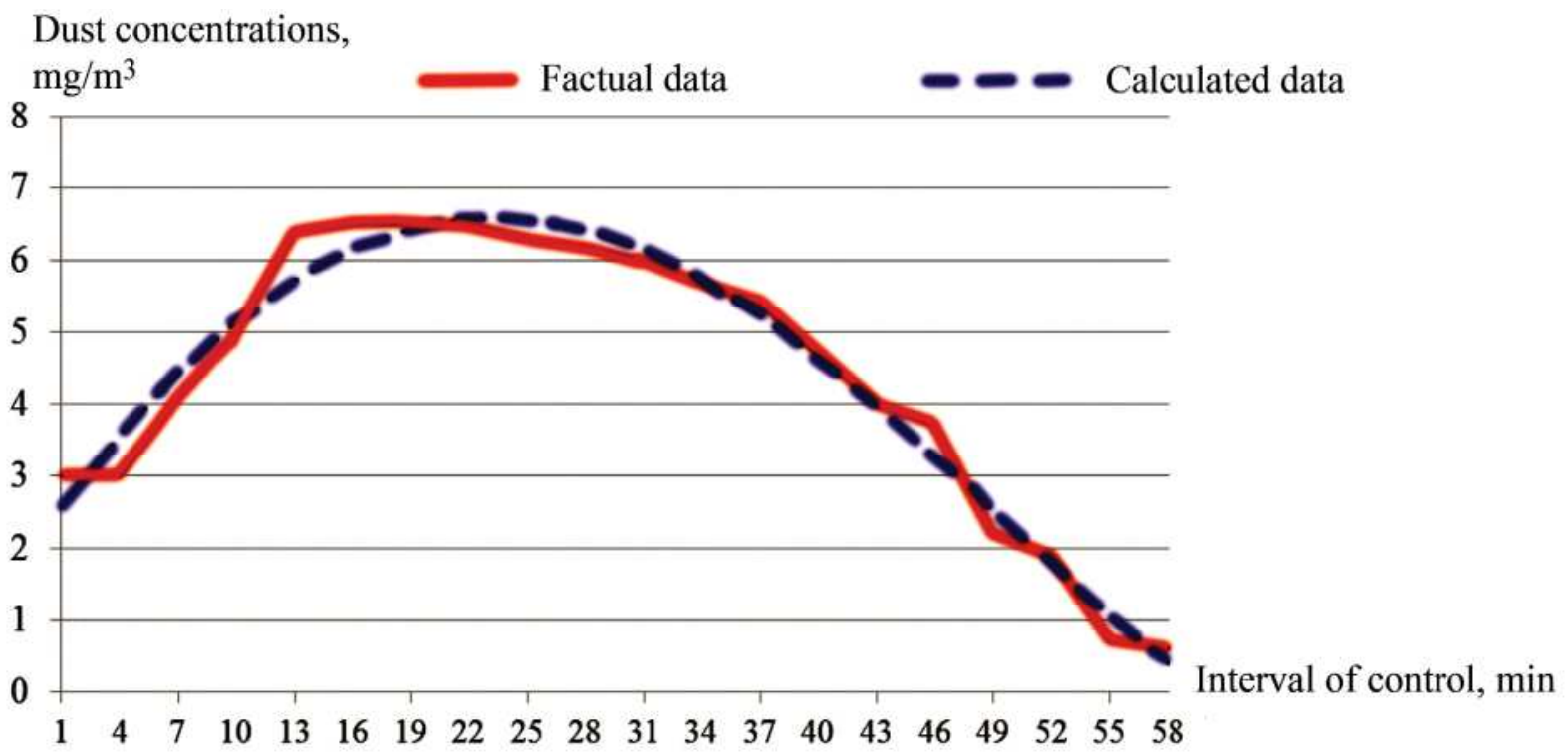

Fig. 3. Dust concentrations dynamics in the workplace (factual and calculated data) 
It was established that in accordance with [21] a significant part of the working time on the dust factor is spent in harmful working conditions (see Tab. 1). The main component in dustiness in the working areas of transportation, preparation and mixing of materials is $\mathrm{SiO}_{2}$ (concentration of more than 60\%). Its maximum permissible concentration (MPC) is $1 \mathrm{mg} / \mathrm{m}^{3}$. Therefore, working conditions correspond to subclass 3(1) (exceeding the MPC in 1.1...3.0 times) and subclass 3(2) (exceeding the MPC in 3.1..10.0 times), that is, measures are needed to improve working conditions.

\subsection{Workplace vibration level values modelling and forecasting}

The vibration level values dynamics was analyzed for experimental data that are shown in Figure 1.

Since the variation in mathematical expectation for this factor is $12.35 \%$, which is within $15 \%$, the process is conditionally stationary. The forecast calculation results for the selected values in accordance with equation (1) are shown in Table 6.

Table 6.

The predicted values calculation results of the vibration level

\begin{tabular}{|c|c|c|c|c|c|c|c|}
\hline \multirow{3}{*}{$\begin{array}{l}\text { Interval of } \\
\text { control, min }\end{array}$} & \multirow{2}{*}{ Factual data } & \multicolumn{6}{|c|}{ Predicted values calculation results } \\
\hline & & \multicolumn{2}{|l|}{$\alpha=0.3$} & \multicolumn{2}{|l|}{$\alpha=0.2$} & \multicolumn{2}{|l|}{$\alpha=0.5$} \\
\hline & $x(t), d B A$ & $y(t), d B A$ & $\begin{array}{l}\text { Absolute } \\
\text { error }\end{array}$ & $y(t), d B A$ & $\begin{array}{l}\text { Absolute } \\
\text { error }\end{array}$ & $y(t), d B A$ & $\begin{array}{l}\text { Absolute } \\
\text { error }\end{array}$ \\
\hline 1 & 92 & & & & & & \\
\hline 8 & 90 & 97.72 & -7.72 & 106.69 & -16.69 & 112.34 & -1.00 \\
\hline 15 & 92 & 95.40 & -3.40 & 103.35 & -11.35 & 110.11 & 0.10 \\
\hline 22 & 92 & 94.38 & -2.38 & 101.08 & -9.08 & 108.30 & 0.09 \\
\hline 29 & 115 & 93.67 & 21.33 & 99.27 & 15.73 & 106.67 & 0.08 \\
\hline 36 & 120 & 100.07 & 19.93 & 102.41 & 17.59 & 107.50 & -0.93 \\
\hline 43 & 122 & 106.05 & 15.95 & 105.93 & 16.07 & 108.75 & 0.17 \\
\hline 50 & 120 & 110.83 & 9.17 & 109.14 & 10.86 & 110.07 & 6.15 \\
\hline 57 & 120 & 113.58 & 6.42 & 111.32 & 8.68 & 111.07 & 9.53 \\
\hline 64 & 125 & 115.51 & 9.49 & 113.05 & 11.95 & 111.96 & -10.42 \\
\hline 71 & 126 & 118.36 & 7.64 & 115.44 & 10.56 & 113.26 & -10.38 \\
\hline 78 & 126 & 120.65 & 5.35 & 117.55 & 8.45 & 114.54 & -7.34 \\
\hline 85 & 126 & 122.25 & 3.75 & 119.24 & 6.76 & 115.68 & -5.61 \\
\hline 92 & 127 & 123.38 & 3.62 & 120.59 & 6.41 & 116.72 & -10.05 \\
\hline 99 & 126 & 124.46 & 1.54 & 121.88 & 4.12 & 117.74 & -9.04 \\
\hline 106 & 127 & 124.93 & 2.07 & 122.70 & 4.30 & 118.57 & -8.14 \\
\hline 113 & 127 & 125.55 & 1.45 & 123.56 & 3.44 & 119.41 & -5.32 \\
\hline 120 & 122 & 125.98 & -3.98 & 124.25 & -2.25 & 120.17 & 12.21 \\
\hline 127 & 92 & 124.79 & -32.79 & 123.80 & -31.80 & 120.35 & 14.99 \\
\hline \multirow[t]{2}{*}{134} & 90 & 114.95 & -24.95 & 117.44 & -27.44 & 117.52 & 8.49 \\
\hline & & & 8.97 & & 11.05 & & 12.34 \\
\hline
\end{tabular}




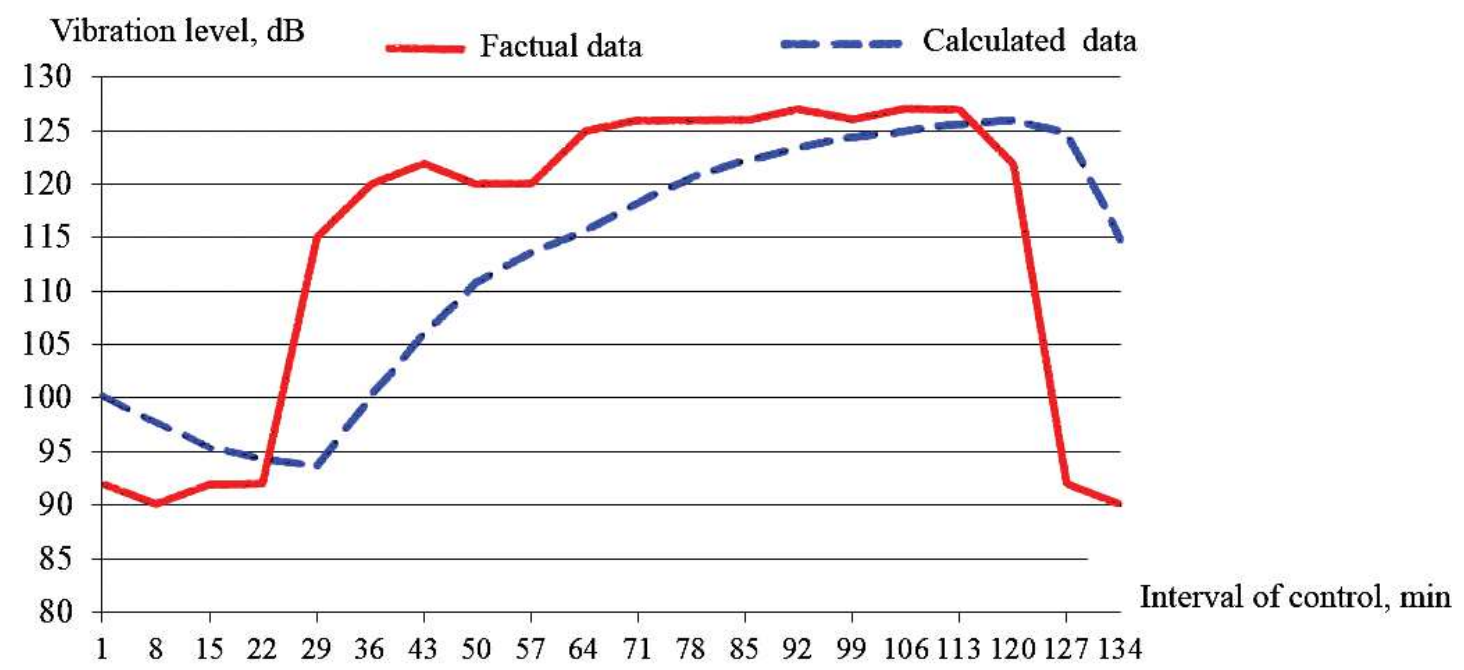

Fig. 4. Vibration level dynamics in the workplace (factual and calculated data)

It is established that the best results of predicting vibration indicators are obtained for the smoothing coefficient. The sample for forecasting was the first six points, and the control sample was 14 calculated forecast points. The relative forecast error is $8.97 \%$. The forecast model of vibration level values has the form:

$y(t)=0.3 \cdot x(t-7)+0.7 \cdot S(t-8)$,

$S(0)=\frac{1}{6} \sum_{i=1}^{6} x(7(i-1)+1)$

The predicted values calculation results of the vibration level are shown in Table 6 and the graphical representation of the dynamics of the factual and calculated values of the vibration level are shown in Figure 4.

Thus, it was found that, according to [21], a considerable part of working time is spent in hazardous working conditions, the excess of $112 \mathrm{~dB}$ in some cases more than $12 \mathrm{~dB}$ is recorded (see Fig. 4), which corresponds to the class of conditions labour -4 (dangerous working conditions) and requires measures to improve safety.

\subsection{Workplace relative humidity level values modelling and forecasting}

The dynamics of relative humidity values was analyzed for experimental data that are shown in Figure 1.

It is established that the humidity index model is conditionally stationary in nature, and it is possible to distinguish the trend component, and the remainder will satisfy the condition of limiting the variation of the mathematical expectation of the remainder within $15 \%$. That is, the trend component of the process of physical factor values changing and the stationary component can be highlighted [20]:

$x(t)=x_{1}(t)+x_{2}(t)$

where $\mathrm{x}(\mathrm{t})$ - the workplace environmental physical factors value which is investigated; $x_{1}(t)$ - the value of the trend component of the process; $x_{2}(t)-$ the value of the stationary component of the process.

The polynomial regression method is proposed to predict the trend part of the forecast models of conditionally stationary processes. For conditional stationary processes, the control interval was determined by its stationary part [20].

To highlight the trend component of the indicator, a fourth-order trend mathematical model is created in accordance with equation (3)

$$
y_{1}(t)=97.07-0.8 \cdot t+0.0053 \cdot t^{2}-0.000067 \cdot t^{3}
$$

The correlation coefficient for the model is $\mathrm{R}=0.90$.

To construct the stationary component of the indicator, we form the initial data $x_{2}$ as the difference of values $x(t)$ and $y_{1}(t)$. The data obtained demonstrate a conditionally stationary process. 
According to the calculation results shown in Table 7, it was found that the best results for predicting the relative humidity level were obtained for the smoothing coefficient. The forecast model of the stationary component of the relative humidity level changes at the workplace will have the form:

$\mathrm{y}_{2}(\mathrm{t})=0.3 \cdot \mathrm{x}_{2}(\mathrm{t}-10)+0.7 \cdot \mathrm{S}(\mathrm{t}-11)$

$\mathrm{S}(0)=\frac{1}{6} \sum_{\mathrm{i}=1}^{6} \mathrm{x}_{2}(10(\mathrm{i}-1)+1)$

The mathematical model of the relative humidity values dynamics in the working area of transportation, preparation and mixing of materials has the form:

$$
\begin{aligned}
& y(t)=97.07-0.8 \cdot t+0.0053 t^{2}-0.000067 t^{3}+ \\
& +0.3\left(x(t-10)-97.07-0.8 t+0.0053 t^{2}+0.000067 t^{3}\right)+ \\
& +0.7 \cdot S(t-11) \\
& \mathrm{S}(\mathrm{t}-1)=0.3 \cdot\left(\mathrm{x}(\mathrm{t}-10)-97.07-0.8 \cdot \mathrm{t}+0.0053 \mathrm{t}^{2}-0.00006 \mathrm{t}^{3}\right)+ \\
& +0.7 \cdot \mathrm{S}(\mathrm{t}-11) \\
& \mathrm{S}(0)=\frac{1}{6} \sum_{\mathrm{i}=1}^{6} \mathrm{x}_{2}(10 \cdot(\mathrm{i}-1)+1) .
\end{aligned}
$$

\begin{tabular}{|c|c|c|c|c|c|}
\hline \multicolumn{2}{|l|}{ Factual data } & \multicolumn{4}{|c|}{ Predicted values calculation results } \\
\hline $\begin{array}{l}\text { Interval of control, } \\
\text { min }\end{array}$ & $x(t), \%$ & $y(t), \%$ & Absolute error & $\mathrm{y}_{1}(\mathrm{t}), \%$ & $\mathrm{y}_{2}(\mathrm{t}), \%$ \\
\hline 1 & 89 & & & & \\
\hline 11 & 89 & 86.16 & 2.98 & 88.90 & -1.95 \\
\hline 21 & 85 & 80.61 & 2.37 & 82.55 & -2.10 \\
\hline 31 & 85 & 75.09 & 18.44 & 77.18 & -3.81 \\
\hline 41 & 78 & 68.94 & 3.50 & 72.75 & -4.24 \\
\hline 51 & 73 & 64.98 & 0.91 & 69.22 & -4.10 \\
\hline 61 & 67 & 62.44 & 5.99 & 66.55 & -3.01 \\
\hline 71 & 60 & 61.69 & 10.85 & 64.69 & -0.70 \\
\hline 81 & 57 & 62.92 & 9.03 & 63.62 & 1.50 \\
\hline 91 & 57 & 64.78 & 5.26 & 63.28 & 2.93 \\
\hline 101 & 63 & 66.57 & 2.27 & 63.64 & 2.24 \\
\hline 111 & 65 & 66.90 & 2.33 & 64.66 & 1.47 \\
\hline 121 & 65 & 67.76 & 0.14 & 66.30 & 1.42 \\
\hline 131 & 67 & 69.93 & 0.07 & 68.51 & 1.44 \\
\hline 141 & 73 & 72.71 & 2.26 & 71.26 & 0.49 \\
\hline 151 & 75 & 75.00 & 0.65 & 74.51 & 0.20 \\
\hline 161 & 85 & 78.42 & 4.33 & 78.22 & -1.90 \\
\hline 171 & 90 & 80.45 & 3.37 & 82.34 & -3.62 \\
\hline 181 & 86 & 83.22 & 2.47 & 86.84 & -2.28 \\
\hline 191 & 84 & 89.40 & 5.22 & 91.68 & -2.74 \\
\hline & & & 4.34 & & \\
\hline
\end{tabular}

The graphical representations of the dynamics of the factual and calculated values of the relative humidity (RH) level are shown in Figure 5.

Table 7.

The predicted values calculation results of the relative humidity level 


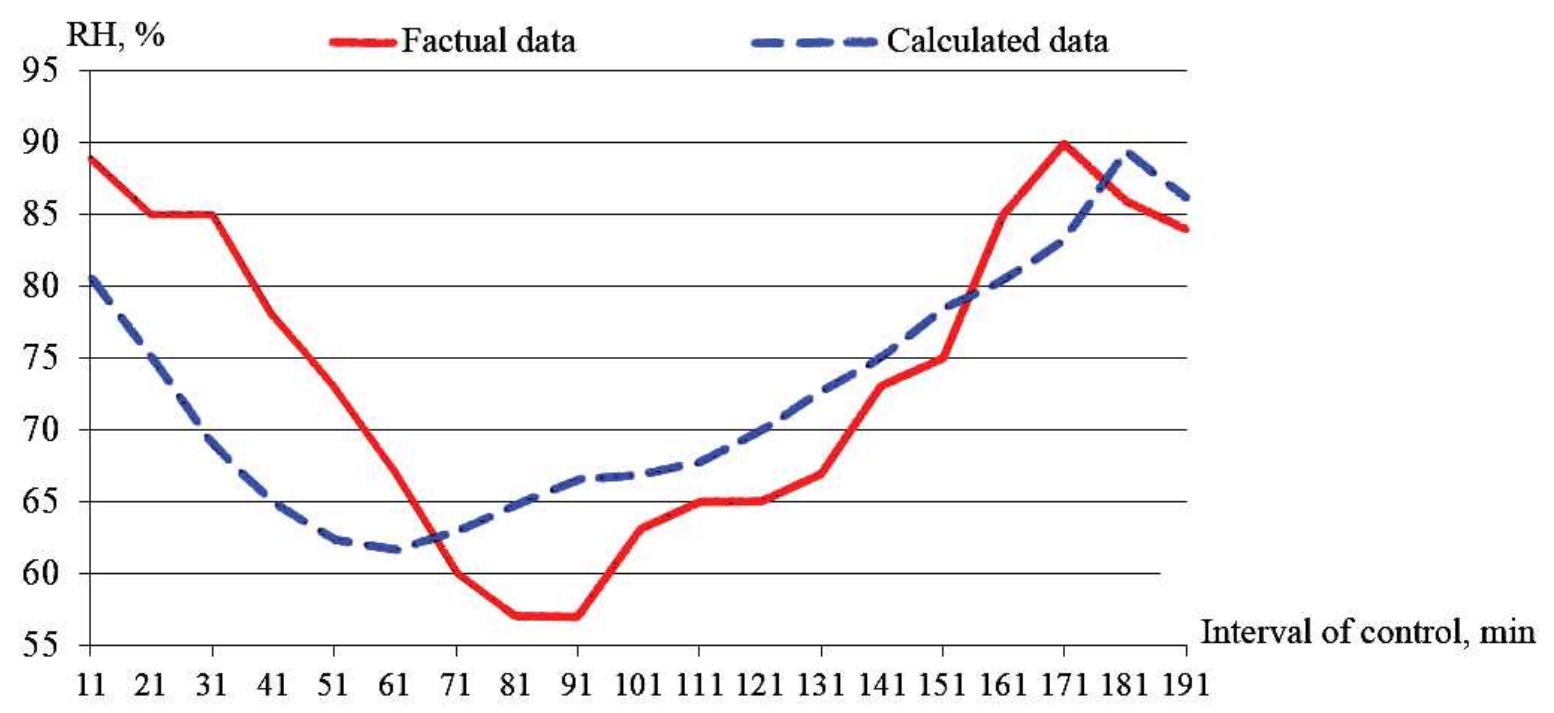

Fig. 5. Relative humidity level values dynamics in the workplace (factual and calculated data)

An analysis of the relative humidity values dynamics indicates that a significant part of the workers' working hours is spent in harmful working conditions (an excess of the relative humidity of $75 \%$ is observed in the cold season). Therefore, measures are needed to improve working conditions.

Thus, in this study, mathematical models for predicting values of four workplace environmental physical factors are obtained. Each model is based on a certain control interval of values for these factors and allows you to set with a given accuracy:

- Adequately assess working conditions at workplaces and classify them by indicators of harmfulness and danger of factors of the working environment;

- Provide informed planning of measures to improve working conditions;

- Evaluate the results of the implementation of planned activities.

\section{Conclusions}

Based on the results of theoretical and experimental studies, the following conclusions are formulated:

1. For a preliminary assessment of the impact of environmental physical factors on workers, it is proposed to use the strict ranking method. This made it possible to order the discovered physical factors according to the degree of danger and harmfulness.

2. It has been established that the proposed mathematical models for predicting the workplace environmental physical factors values (noise, dust, vibration, relative humidity) have an accuracy of more than $90 \%$ and can be used for planning measures to working conditions improve.

\section{Acknowledgements}

The authors' team is grateful to the administration of the Public Agency "National Research Institute of Industrial Safety and Occupational Safety and Health" and National Technical University of Ukraine "Igor Sikorsky Kiev Polytechnic Institute" for the opportunity to conduct scientific research.

\section{Additional information}

The work was carried out within the scientific studies framework on the subjects of the Public Agency "National Research Institute of Industrial Safety and Occupational Safety and Health" and National Technical University of Ukraine "Igor Sikorsky Kiev Polytechnic Institute".

\section{References}

[1] S. Tak, R.R. Davis, G.M. Calvert, Exposure to hazardous workplace noise and use of hearing protection devices among US workers - NHANES, 
1999-2004, American Journal of Industrial Medicine 52/5 (2009) 358-371, DOI: 10.1002/ajim.20690.

[2] M. Milenović, S. Živković, M. Veljković, Noise and Aggressiveness in the Workplace, in: N. Herisanu, V. Marinca (Eds.), Acoustics and Vibration of Mechanical Structures - AVMS-2017: Proceedings of the 14th AVMS Conference, Timisoara, Springer Proceedings in Physics 198, Springer, 2018, 99-104, DOI: 10.1007/978-3-319-69823-6_12.

[3] S. Ragimov, V. Sobyna, S. Vambol, V. Vambol, A. Feshchenko, A. Zakora, E. Strejekurov, V. Shalomov, Physical modelling of changes in the energy impact on a worker taking into account high-temperature radiation, Journal of Achievements in Materials and Manufacturing Engineering 91/1 (2018) 27-33, DOI: 10.5604/01.3001.0012.9654.

[4] M. Asghari, P. Nassiri, M.R. Monazzam, F. Golbabaei, H. Arabalibeik, A. Shamsipour, A. Allahverdy, Weighting Criteria and Prioritizing of Heat stress indices in surface mining using a Delphi Technique and Fuzzy AHP-TOPSIS Method, Journal of Environmental Health Science and Engineering 15/1 (2017) 1, DOI: 10.1186/s40201-016-0264-9.

[5] Y. Suhikova, S. Vambol, V. Vambol, N. Mozaffari, N. Mozaffari, Justification of the most rational method for the nanostructures synthesis on the semiconductors surface, Journal of Achievements in Materials and Manufacturing Engineering 92/1-2 (2019) 19-28, DOI: $10.5604 / 01.3001 .0013 .3184$.

[6] O. Tverda, K. Tkachuk, Y. Davydenko, Comparative analysis of methods to minimize dust from granite mine dumps, Eastern-European Journal of Enterprise Technologies 4/10(64) (2016) 15-18, DOI: 10.15587/1729-4061.2016.64840.

[7] S. Vambol, V. Vambol, V. Sobyna, V. Koloskov, L. Poberezhna, Investigation of the energy efficiency of waste utilization technology, with considering the use of low-temperature separation of the resulting gas mixtures, Energetika 64/4 (2018) 186-195, DOI: 10.6001/energetika.v64i4.3893.

[8] S.O. Vambol, I.T. Bohdanov, V.V. Vambol, Y.O. Suchikova, O.M. Kondratenko, T.P. Nestorenko, S.V. Onyschenko, Formation of filamentary structures of oxide on the surface of monocrystalline gallium arsenide, Journal of Nano- and Electronic Physics 9/6 (2017) 06016, DOI: 10.21272/jnep.9(6).06016.

[9] Ž. Janković, M. Mišić, M. Cvetković, Maintenance of work equipment based on vibration diagnosis for the purpose of employees'safety, Facta Universitatis, Series: Working and Living
Environmental Protection 14/2 (2018) 129-138, DOI: 10.22190/FUWLEP1702129J.

[10] K.O. Kobzev, S.A. Shamshura, A.N. Chukarin, A.I. Buryanov, V.E. Kasyanov, Substantiation of the parameters of vibration systems in the cab of the gantry crane at the workplace of crane operators, MATEC Web of Conferences 226 (2018) 01023, DOI: 10.1051/matecconf/201822 0102.

[11] R. Jabbour, S. Turner, L. Hussey, F. Page, R. Agius, Workplace injury data reported by occupational physicians and general practitioners, Occupational Medicine 65/4 (2015) 296-302, DOI: 10.1093/ occmed/kqv014.

[12] D. Sokolov, V. Sobyna, S. Vambol, V. Vambol, Substantiation of the choice of the cutter material and method of its hardening, working under the action of friction and cyclic loading, Archives of Materials Science and Engineering 94/2 (2018) 49-54, DOI: 10.5604/01.3001.0012.8658.

[13] M. Picchio, J.C. Van Ours, Temporary jobs and the severity of workplace accidents, Journal of Safety Research 61 (2017) 41-51, DOI: 10.1016/j.jsr.2017. 02.004 .

[14] A.V. Arundel, E.M. Sterling, J.H. Biggin, T.D. Sterling, Indirect health effects of relative humidity in indoor environments, Environmental Health Perspectives 65 (1986) 351-361, DOI: 10.1289/ehp.8665351.

[15] M. Levin, E. Rojas, E. Vanhala, M. Vippola, B. Liguori, K.I. Kling, I.K. Koponen, K. Mølhave, T. Tuomi, D. Gregurec, S. Moya, K.A. Jensen, Influence of relative humidity and physical load during storage on dustiness of inorganic nanomaterials: implications for testing and risk assessment, Journal of Nanoparticle Research 17/8 (2015) 337, DOI: 10.1007/s11051-015-3139-6.

[16] O. Kruzhilko, V. Maystrenko, Management decisionmaking algorithm development for planning activities that reduce the production risk level, Journal of Achievements in Materials and Manufacturing Engineering 93/1-2 (2019) 41-49, DOI: 10.5604/ 01.3001.0013.4141.

[17] H. Hnenna, Risk assessment of the complex harmful factors, Metallurgical and Mining Industry 1 (2016) 187-190.

[18] O. Kruzhilko, O. Bogdanova, Method of human factor minimization in expert judgement for occupational risk assessment and decision making, Ukrainian Journal of Food Science 4/1 (2016) 138-150.

[19] A.O. Vodyanik, Doslídzhennya prichin riziku virobnichogo travmatizmu bez smertel'nikh naslídkív, 
Problemi Okhoroni Pratsí v Ukraïní 10 (2005) 14-22 (in Ukrainian).

[20] O. Kruzhilko, O. Polukarov, V. Kalinchyk, I. Tkalych, Improvement of the workplace environmental physical factors values monitoring by determining the optimal interval for their control, Archives of Materials Science and Engineering 99/1-2 (2019) 42-49, DOI: 10.5604/01.3001.0013.5881.

[21] Derzhavni sanitarni normy ta pravyla. Hihiyenichna klasyfikatsiya pratsi za pokaznykamy shkidlyvosti ta nebezpechnosti faktoriv vyrobnychoho seredovyshcha, vazhkosti ta napruzhenosti trudovoho protsesu, Nakaz MOZ Ukrayiny vid 08.04.2014 r № 248, Available at: https://zakon.rada.gov.ua/laws/show/ z0472-14 (in Ukrainian).
[22] P.J. Brockwell, R.A. Davis, Time Series: Theory and Methods, Second Edition, Springer, New York, 2009, 273.

[23] N.R. Draper, H. Smith, Applied Regression Analysis, Third edition, Wiley-Interscience, 1998, 736.

[24] YU.P. Lukashin, Adaptivnyye metody kratkosrochnogo prognozirovaniya vremennykh ryadov, Moskva: Finansy i statistika, 2003, 415 (in Russian).

[25] K.N. Tkachuk, V.V. Kalinchyk, Modeli prohnozuvannya rozvytku nebezpechnykh i shkidlyvykh chynnykiv vyrobnychykh ob"yektiv, Visnyk Kremenchuts'koho Natsional'noho Universytetu imeni Mykhayla Ostrohrads'koho 6(89) (2014) 143-147 (in Ukrainian). 